\title{
The Effects of Globalization on Application of Environmental Management System (EMS)
}

\author{
Hana Kopackova ${ }^{1, *}$, and Alena Zelena ${ }^{1}$ \\ ${ }^{1}$ University of Pardubice, Faculty of Economics and Administration, Institute of System Engineering \\ and Informatics, Studentska 84, 53210 Pardubice, Czech Republic
}

\begin{abstract}
.
Research background: Environmental management systems (EMS) is an international standard of best practices for managing impacts on the natural environment. The standard came into effect in 1996. The EMS reviews the environmental aspects and sets goals and targets for managing them. EMS is based on continuous development (Plan - Do - Check - Act). It is one of the voluntary instruments, as the obligation to introduce an EMS is not contained in any legal regulation. The mainstream of thoughts shows that globalization enforces EMS implementation mainly by sharing knowledge (best practices), but more aspects should be investigated.

Purpose of the article: The article aims to formulate a conceptual model of globalization effects on the application of EMS and to document these effects on the selected company.

Methods: A review of EMS literature is used to determine globalization's positive and negative aspects of this field. To construct the model, we use the business process modelling tool Adonis CE. A case study of a selected company shows how these aspects affect the ability to adhere to its environmental policy.

Findings \& Value added: The article revealed a conceptual model of globalization effects on EMS. The presented case study showed the interconnection of individual effects and impact on the company's effectiveness.
\end{abstract}

Keywords: EMS; environment; globalization; best practices; model

JEL Classification: $Q 53$

*Corresponding author: hana.kopackova@upce.cz 


\section{Introduction}

An environmental management system is a system that focuses on those activities of the company that could have a negative impact on the environment and the health of the population. With the introduction of the environmental management system, the company expresses its willingness to contribute to its protection and the population's health. At present, this system is becoming a standard within companies, and its implementation is also one of the customer requirements [12].

Currently, there are two regulations based on which environmental management can be implemented. The first of them is a technical standard of the ISO series; exactly ISO 14001 called the environmental management system. The second regulation for implementation is Regulation No. 761/2001 of the European Parliament and the Council on organizations' voluntary participation in corporate governance and audit for environmental protection. Suppose companies voluntarily decide to implement an environmental management system called EMS. In that case, they are regularly reviewed (audited) based on the regulation according to which the system was implemented in the organization $[9,12]$.

The established environmental management system (EMS) provides tools and principles for the top management. Environmental management requires the organization to monitor and identify environmental impacts in order to achieve improvements in these areas [5]:

- reduction tools - reducing the burden on air, water, rocks, soil, organisms, ecosystems, and energy,

- information tools - to inform customers and other stakeholders about its environmentally friendly approach,

- educational tools - to ensure that environmental issues are adequately understood throughout the company.

\section{Methods}

The first part of the research concerns development of the EMS life cycle model based on the literature review. This model forms the necessary foundation for revealing the effect of globalization on the application of EMS. Data collection for literature review was held through May and June 2020. The plan was to incorporate only high-quality articles and papers. Therefore, we used the Web of Science database as the source of data. The search phrase "environmental management system" brought 1120 hits. Next phase included search through the abstracts for terms: "Globalization", "Global", International", and "Adoption". After removing duplicates, there were 340 articles in the selection. A thorough reading of abstracts revealed 16 articles focused on EMS adoption factors, application of EMS, and global influence. The conceptual model of the EMS life cycle and model of globalization effects were prepared based on this literature review.

The second part of the research focused on the case study, where identified effects of globalization in both phases of the life cycle (adoption, application) were discussed on the example of a company from the automotive industry. An example of a real problem solution depicts opportunities that are open in the global society.

\section{Results}

\subsection{Life cycle of EMS and the role of globalization}

The literature review revealed two fundamental phases of the EMS life cycle: adoption and application. The most critical phase and most cited in the research is the adoption phase, 
which can last for long. In this phase, companies are considering all pros and cons of the implementation of EMS. There are mainly two views on this issue: 1) what factors influence the decision-making process and drive companies into the decision (adoption factors), and 2) what qualities possess companies that decided to adopt EMS (mediating factors). Mediating factors are based on the company's characteristics as size, application of quality management system, health and safety management system, export orientation, employee commitment, and research and development [2, 3]. Adoption factors can be divided into three categories - two of them acting for acceptance and one against. Perceived benefits and perceived pressure work together towards the implementation of EMS, but there is a vast difference in the perception of the adopting company. While perceived benefits are voluntarily chosen and represent something that the company wants, perceived pressure has negative connotation. The company is forced to change its policy and accept new norms in the form of EMS. Even though this instrument (pressure) is mostly perceived negatively by companies, this is a useful tool for disseminating environmental protection measures. On the other hand, there are also some barriers that block or slow down the implementation of EMS. Adoption factors, together with the whole EMS life cycle, are depicted in figure 1.

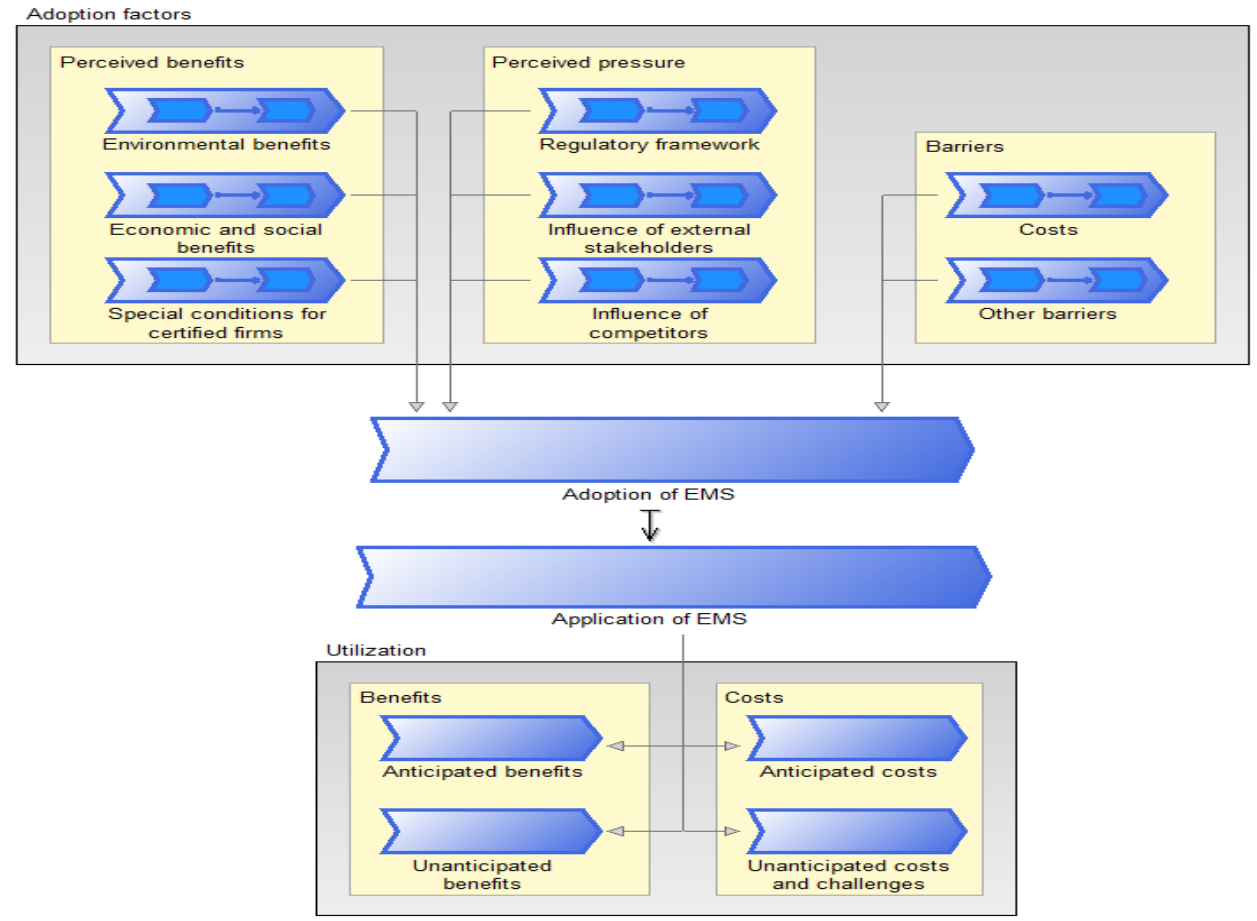

Fig. 1. The life cycle of EMS.

EMS's voluntariness is expressed by perceived benefits (see figure 2), which stands for positive expectations resulting from EMS application in a particular organization. Benefits mentioned by various researchers through literature review can be divided into three categories: 1) environmental benefits, 2) economic and social benefits, and special conditions for certified firms $[7,8,9,12,16]$. Environmental benefits are the most obvious reason why companies implement environmental management. However, the motive for implementing EMS may not be entirely altruistic, just concerning environmental protection. Companies are merely earnings oriented, which means that economic and social benefits are also significant. Especially savings in raw material and energy can be viewed as the 
driver. Green corporate image is another factor motivating the company if its customers appreciate this quality. One particular category of benefits is more difficult to quantify special conditions for certified firms. These benefits are mostly linked to the process of permit renewal and preparation of technical reports.

\begin{tabular}{|lll|}
\hline Environmental benefits: & Economic and social benefits: & Special conditions for certified firms: \\
- Reduction of air polution & - Energy savings & Permit renewal by self- \\
- Reduction of water polution & - Savings in raw materiál & certification \\
- Reduction in noise, smell, vibration, & - Tax reduction & Expansion of environmental \\
visual impact & permit duration \\
- Reduction in soil contamination & - Increase in turnover & Reduction of technical reports \\
- Reduction in risk of industrial & - Green corporate image & Reduction of inspection frequency \\
- Effect on biodiversity & - Alignment of other company's QMS & Advantages in public tenders \\
- Reduction of waste generation & &
\end{tabular}

Fig. 2. Perceived benefits.

The process of EMS implementation does not have to be entirely voluntary. Company decisions are often influenced by pressure (see figure 3) from the regulatory framework and influence of its stakeholders and competitors $[1,5,7,12,16,17]$. While the regulatory framework is valid for all companies in the industry, stakeholders and competitors' influence can differ. Customer pressure is highly influenced by standardisation as certificates (EMAS, ISO 14001) bring the information about EMS application to the customers, even if they do not have information about the actual company's environmental practice. On the other hand, shareholders have better access to information about corporate environmental commitment; thus, they can influence managers to demonstrate their interest in sustainable behaviour.

\begin{tabular}{|c|c|c|}
\hline $\begin{array}{l}\text { Regulatory framework: } \\
\text { - } \quad \text { National law and standards } \\
\text { - } \quad \text { International law and standards }\end{array}$ & $\begin{array}{ll}\text { Influence of stakeholders: } \\
\text { - } & \text { Public authorities } \\
\text { - } & \text { Industrial associations } \\
\text { - } & \text { Environmental activists } \\
\text { - } & \text { Banks and other institutions } \\
\text { - } & \text { Customers } \\
\text { - } & \text { Parent company } \\
\text { - } & \text { Suppliers } \\
\text { - } & \text { Shareholders }\end{array}$ & $\begin{array}{l}\text { Influence of competitors: } \\
\text { - Green strategy of current } \\
\text { competitors } \\
\text { - Planed expansion into new market } \\
\text { segment with new competitors }\end{array}$ \\
\hline
\end{tabular}

Fig. 3. Perceived pressure.

Costs and other barriers (see figure 4) have negative effect on the implementation of EMS $[7,8,9,12,14,17]$. Obtaining and maintaining registration is a costly process that may discourage companies from implementation. However, costs are only one side of the coin. More complex problems represent other barriers, especially those rooted in people's thinking. Lack of awareness is the smallest of them as sharing of information can solve this problem. Unfortunately, the resistance of managers and other staff is much difficult to overcome, if they perceive the whole process of implementation and application of EMS as too complex and demanding. In this case, benefits are weak factors that can not drive the implementation itself. Without perceived pressure, companies mostly resist the implementation of EMS. 


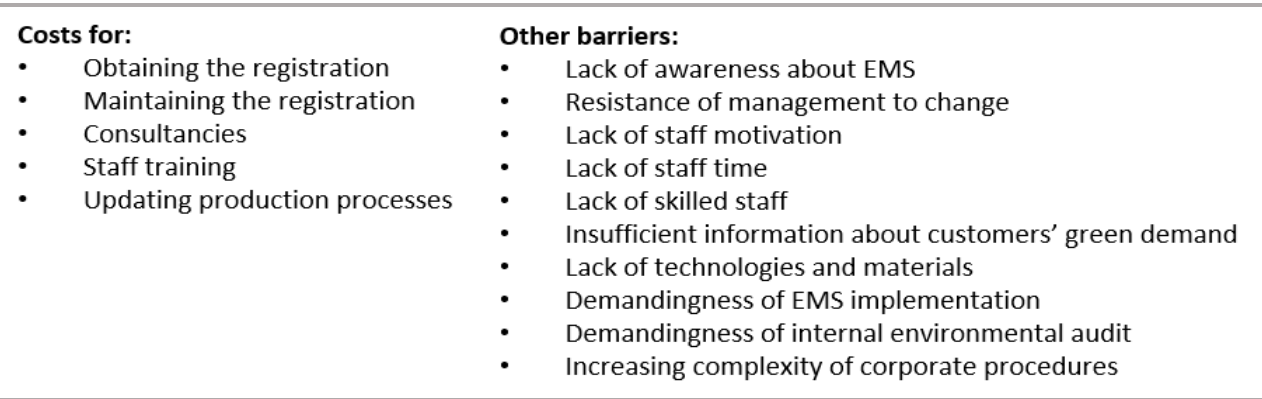

Fig. 4. Costs and other barriers.

Based on the EMS life cycle model, we derive the model of globalization effects on EMS application (see figure 5). As the first problem for the implementation process was identified, lack of information, which means that all stakeholders (companies itself, their customers and suppliers, regulators, etc.) have to know what is possible. This assumption covers the information about trends in new materials, new processes, and even new market opportunities. The second problem forms uncertainty about how to implement EMS in a particular company. This uncertainty can manifest as the resistance either on the managerial or staff level. The third problem in EMS application is that even if companies claim their sustainable behaviour, consumers have no means to prove this claim. Globalization helped to solve all these problems with the rise of international standards. Environmental protection methods and ways of sustainable behaviour are evolving, but best practices can be shared and applied worldwide due to standardization. Customers in different parts of the world can be assured about this behaviour based on the applied standards and eco labels. We can say that globalization is the core process that enabled the development of an environmental management system worldwide.

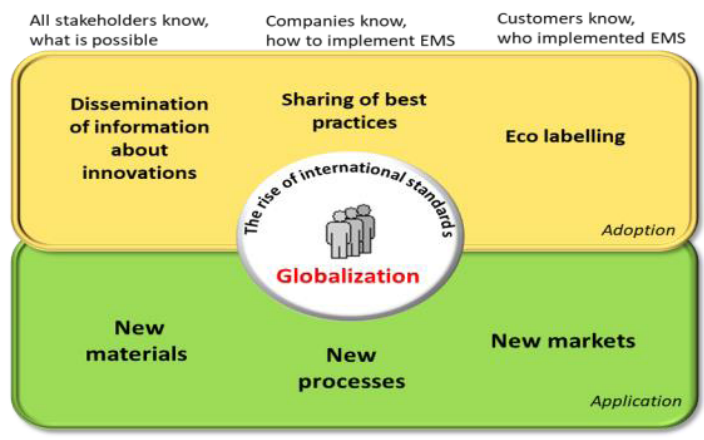

Fig. 5. Model of globalization effects on EMS application

\subsection{Case study}

The studied company is involved in the automotive industry and based in the Czech Republic. It is part of an international automotive company, functioning as a business unit division with global competencies in its business area. Environmental management is a support process for the entire division, both for production and administrative areas. The critical elements of the company's environmental management include waste management and water management. EMS in this division is implemented by the Department of Environment, Safety, and Health (ESH). 
As part of the continuous improvement of processes and achieved results, the company sets its goals every year, based on the evaluation of environmental aspects. The management of the company enters the requirement to reduce the production of adverse effects on the environment. Every year, the same goal is set compared to the previous year's final value, i.e., a $2 \%$ reduction in electricity consumption or waste production.

The measured quantities of key indicators are monitored and saved in the internal statistics of the ESH department. To make the evaluation comparable across the company, individual consumption is measured per 1000 pieces produced. This allows an objective view of consumption and also allows effective monitoring and comparison between locations.

In addition to corporate goals, the company also sets its local goals, programs, and projects, which it seeks to achieve. Monitoring is listed in a corporate table called "Objective, Targets, and Programs".

Waste management - Waste management is an essential and integral part of the company's economic activities. The company pays for the disposal of waste and, at the same time, accepts payments for selling recyclable material (mostly generated by the plastics press department). Current developments in the markets for these commodities do not show a very satisfactory trend, so waste management must become one of the main topics that society should be interested in.

Water management - Consumption and water use are indispensable for the plant's operation, although water is not primarily used for production technology as there are only a few machines in the plant that must be connected to water - for example, for cooling or product testing. Furthermore, water is used to wash used packaging materials. This is only a fraction compared to consumption by employees during the regular operation of the plant. The plant's undeniable advantage within water management is the possibility of using its own well, which includes certain economic benefits in water payment.

\subsubsection{Adoption factors}

The plant began planning the implementation of EMS in 1999 in connection with the existing certified ISO 9000 system. During 1999, an initial environmental review was submitted, which was carried out with an external consulting company's professional support. The aim was to find out the company's current environmental profile and set priorities in implementing a functional EMS. In the first phase, a workshop focused on integrating the environmental management system was held. The then environmental policy was presented - which was also a framework for implementing the environmental management system. As part of the EMS implementation, old environmental burdens from the original industrial activity (textile production) were also assessed. The audit concluded that the soil was only slightly polluted by previous activities and did not require remediation, and water was not polluted. Air pollution from flue gases from the boiler room was solved by purchasing gas boilers. The initial review also provided additional measures that had to be put in place for successful certification. It was mainly about keeping records of energy consumption, formalities in the management of hazardous chemicals and waste, the use of recyclable materials in production, and maintenance had to be resolved, environmental aspects were included in emergency plans, and a system of training and audits was introduced. The audit for the verification of the implemented EMS system took place on September 7, 1999, based on which the company received a valid ISO 14001 certificate.

According to adoption factors, we can find the one that made all other unimportant, and it is a requirement of the parent company located in Germany. Foreign ownership was identified as an essential determinant of EMS adoption even in research literature $[1,15$, 
16], and emphasizes the role of globalization. Although the adoption driver was evident, we interviewed the described company representatives about their view on perceived benefits and barriers of EMS implementation. As the main benefit of EMS adoption, they mentioned knowledge sharing and benchmarking.

On the other hand, they see the high costs of the implementation of the EMS system. Hiring a certified company to confirm the eligibility under ISO 14001 is not a cheap affair, and the same is true for subsequent verification audits. Customer requirements are constantly evolving and have higher demands. At present, it is no longer enough to have only 14001 in place - other requirements are ISO 50001 (energy) and ISO 45001 (former 18001) OHSAS (OSH). Moreover, leaning towards the European Union's policy, which seeks "zero emissions" is also difficult for this particular company. The most considerable emission burden is from electricity consumption (so-called indirect emissions), which can be compensated by buying so-called "green energy" but it is much more expensive than non-green energy.

\subsubsection{Application of EMS - example of waste reduction}

The described company has to solve the problem with the amount of waste generated. As for the structure of the produced waste, the majority part consists of recyclable materials (so-called recyclates) in $500 \mathrm{t}$ per year. Another item in the structure is landfill waste; this waste includes municipal waste and possibly construction debris. The last item of the structure is hazardous waste, among which are mainly packaging from cleaning agents' preparations, oils, etc. Structure of waste is depicted in figure 6.

From the financial point of view of waste management, the development is no longer satisfactory. Waste disposal costs are increasing from year to year. In 2019, the total annual amount for waste disposal was $816,952 \mathrm{CZK}$, which is a $25 \%$ higher amount with an equal volume of waste as in 2018. The most expensive waste disposal items are municipal waste disposal where the price for landfilling is around CZK 5,000/t of waste, then the disposal of hazardous waste with amounts of around CZK 9.000/t.

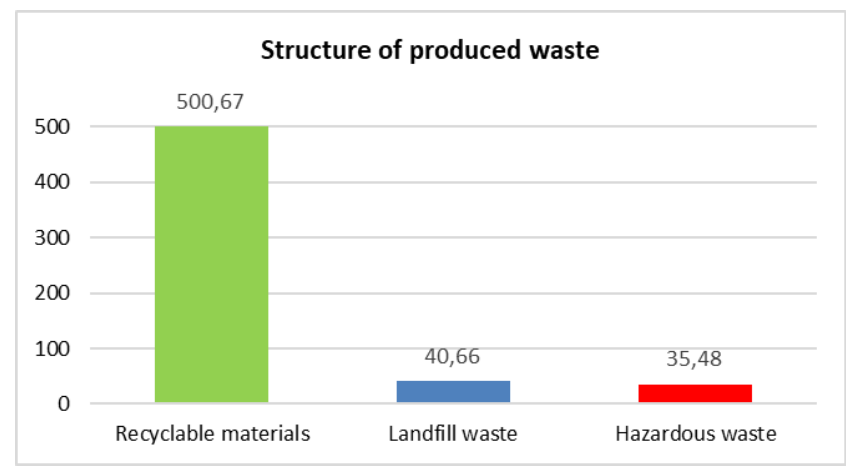

Fig. 6. Types of waste produced by the described company.

The largest area in recyclable materials is the production of plastic waste formed at the plastics press department. This plastic waste is carefully sorted according to the materials used to be offered for further processing. The largest item is material POM, which is polyoxymethylene. The main advantage of this material is considerable rigidity and low tendency to wear. Other types of plastic waste are polyamide and polycarbonate. 
Table 1. Quantity and revenue of recyclable waste

\begin{tabular}{|c|c|c|c|c|c|c|c|c|}
\hline $\begin{array}{c}\text { Plastic } \\
\text { waste } \\
\text { type }\end{array}$ & \multicolumn{2}{|c|}{2016} & \multicolumn{2}{c|}{2017} & \multicolumn{2}{c|}{2018} & \multicolumn{2}{c|}{2019} \\
\hline & $\begin{array}{c}\text { Quantity } \\
\text { t }\end{array}$ & $\begin{array}{c}\text { Revenue } \\
\text { CZK }\end{array}$ & $\begin{array}{c}\text { Quantity } \\
\text { t }\end{array}$ & $\begin{array}{c}\text { Revenue } \\
\text { CZK }\end{array}$ & $\begin{array}{c}\text { Quantity } \\
\text { t }\end{array}$ & $\begin{array}{c}\text { Revenue } \\
\text { CZK }\end{array}$ & $\begin{array}{c}\text { Quantity } \\
\text { t }\end{array}$ & $\begin{array}{c}\text { Revenue } \\
\text { CZK }\end{array}$ \\
\hline POM & 122.4 & $58,931.9$ & 138.6 & 69,289 & 142.56 & 71,279 & 137.9 & $-49,474.6$ \\
\hline $\begin{array}{c}\text { PA6 } \\
\text { PA 6.6 }\end{array}$ & 28.3 & $190,513.6$ & 21.9 & 150,325 & 21 & 147,203 & 26.3 & $66,941.9$ \\
\hline PP/PE & 9.9 & $47,210.2$ & 6.7 & 26,900 & 6.2 & 24,600 & 15.1 & $29,984.7$ \\
\hline PP/PA & 6.6 & $25,364.4$ & 1.2 & 4,620 & 2.1 & 5,325 & 9.9 & 967.5 \\
\hline TPE-S & 0.1 & 0 & 0.5 & 0 & 0.4 & 0 & 2.1 & $-1,215$ \\
\hline PBT & 2.7 & 0 & 3.1 & 0 & 5.4 & 0 & 6.1 & $-3,264.6$ \\
\hline Total & 170 & $297,631.2$ & 172 & 251,134 & 177.7 & 248,407 & 167.1 & $43,939.9$ \\
\hline
\end{tabular}

The analysis will be further focused on the financial side, which is a plastic recyclates' purchase prices. Table 1 shows the volumes of individual materials and revenues from their sale each year. There is a noticeable dramatic drop in revenue for waste between 2018 and 2019. Within 2019, we show negative values for POM waste, which in practice means payment for the disposal of this waste. This trend is also evident for other types of waste, which never generated income in the past, but it was also unnecessary to pay for their liquidation. If the data for 2018 and 2019 are compared, the company loses about 200000 CZK for the sold recyclates, which is a drop of $82 \%$.

In identifying the causes, it was found that in June 2019, the company changed an external company to ensure the disposal and purchase of waste. The reason should allegedly be the market's situation in the purchase of secondary raw materials for further processing and the increase in prices for waste disposal. Figure 7 is a visualization of the development of revenues from production plastics in individual years.

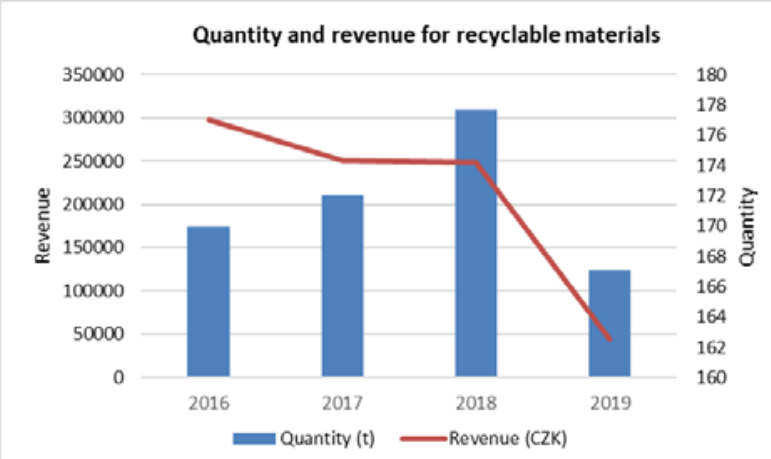

Fig. 7. Progression in the quantity and revenue of recyclable materials.

To summarize the situation, plastic waste is sold to waste treatment companies as part of plastic parts production. The waste is sorted according to individual types of plastic materials, but it is still waste. As the company currently sells its plastic recyclates to a waste treatment company, the recyclates' purchase price is meager. This is mainly because this customer company has to resell the recyclates to another customer specialized in secondary plastics processing. The first problem that this brings is declining prices for 
plastic inlets and rising prices for waste disposal. The second negative factor is the registration of this material as waste.

As part of a standard tender for a waste disposal company, a German company was discovered that is able to purchase plastic inlets as a by-product and, at the same time, offer a much more lucrative purchase price. Therefore, the benefit of the project will have two dimensions - economic benefit - higher prices for plastic waste, and benefit for the environment - reduction of the total waste produced by an average of $140 \mathrm{t} / \mathrm{year}$. This will enable the company to achieve one of its corporate goals. The company's management much appreciated the proposal to develop a project to introduce this new one plastics customer.

The annual income from the sale of the new company's plastics was calculated at CZK 812000 to calculate the future situation while maintaining the average plastic production of $140 \mathrm{t} /$ year. The size of the investment for the establishment of the necessary areas necessary for the start of the project is $1003200 \mathrm{CZK}$. The considered minimum period of operation of the project is determined by a contract for three years with the possibility of further extension. The return on investment period was calculated at 1,24 years; this return is in terms of the company's set standards.

The role of globalization, in this case, is clear and obvious. In the Czech Republic, no company can buy and process plastic recyclates produced by the described company. This material is therefore considered as waste, and its liquidation is costly. The broadening of the market induced by the globalization brought new opportunities.

\section{Conclusion}

This paper brought a new view of EMS's life cycle, which enabled the formation of the model of globalization effects on EMS application. Globalization was revealed as the main driving force of EMS diffusion as it enabled international standardisation. Through standardisation are all stakeholders are assured about the sustainable behaviour of the certified company.

In the case study, we introduced one company from the automotive industry, a business unit located in the Czech Republic of the international enterprise located in Germany. The primary adoption factor was identified as a requirement of the parent company. The unexpected benefit of globalization was finding a German company that can purchase plastic recyclates as a by-product of production. This transaction's economic benefit is the higher price for plastic waste, and the benefit for the environment is the reduction of the total waste produced by an average of $140 \mathrm{t} / \mathrm{year}$. This case study confirmed the role of globalization in both phases of the life cycle. In the adoption phase, it was the influence of foreign ownership. In the application phase, it was finding an international customer that opened a new view and opportunities into recyclates waste management.

\section{References}

1. Bansal, P., Hunter, T. (2003). Strategic explanations for the early adoption of ISO 14001. Journal of Business Ethics, 46(3), 289-299.

2. Darnall, N., Henriques, I., Sadorsky, P. (2008). Do environmental management systems improve business performance in an international setting? Journal of International Management, 14(4), 364-376.

3. Darnall, N., Henriques, I., Sadorsky, P. (2010). Adopting proactive environmental strategy: The influence of stakeholders and firm size. Journal of Management Studies, 47(6), 1072-1094. 
4. King, A. A., Lenox, M. J. (2001). Lean and green? An empirical examination of the relationship between lean production and environmental performance. Production and Operations Management, 10(3), 244-256.

5. Kislingerova, E. Inovace nástrojů ekonomiky a managementu organizací. Praha: C.H. Beck, 2008.

6. Massoud, M. A., Fayad, R., El-Fadel, M., Kamleh, R. (2010). Drivers, barriers, and incentives to implementing environmental management systems in the food industry: A case of Lebanon. Journal of Cleaner Production, 18(3), 200-209.

7. Merli, R., Preziosi, M., Ippolito, C. (2016). Promoting sustainability through EMS application: A survey examining the critical factors about EMAS registration in Italian organizations. Sustainability, 8(3), 197.

8. Murmura, F., Liberatore, L., Bravi, L., Casolani, N. (2018). Evaluation of Italian companies' perception about ISO 14001 and Eco Management and Audit Scheme III: motivations, benefits and barriers. Journal of Cleaner Production, 174, 691-700.

9. Oliveira, J. A., Oliveira, O. J., Ometto, A. R., Ferraudo, A. S., Salgado, M. H. (2016). Environmental Management System ISO 14001 factors for promoting the adoption of Cleaner Production practices. Journal of Cleaner Production, 133, 1384-1394.

10. Prajogo, D., Tang, A. K., Lai, K. H. (2012). Do firms get what they want from ISO 14001 adoption: an Australian perspective. Journal of Cleaner Production, 33, 117126.

11. Qi, G., Zeng, S., Li, X., Tam, C. (2012). Role of internalization process in defining the relationship between ISO 14001 certification and corporate environmental performance. Corporate Social Responsibility and Environmental Management, 19(3), 129-140.

12. Salim, H. K., Padfield, R., Hansen, S. B., Mohamad, S. E., Yuzir, A., Syayuti, K., ... Papargyropoulou, E. (2018). Global trends in environmental management system and ISO14001 research. Journal of Cleaner Production, 170, 645-653.

13. Searcy, C., Morali, O., Karapetrovic, S., Wichuk, K., McCartney, D., McLeod, S., Fraser, D. (2012). Challenges in implementing a functional ISO 14001 environmental management system. International Journal of Quality \& Reliability Management, 29(7), 779-796.

14. Steger, U. (2000). Environmental management systems: Empirical evidence and further perspectives. European Management Journal, 18(1), 23-37.

15. Testa, F., Heras-Saizarbitoria, I., Daddi, T., Boiral, O., Iraldo, F. (2016). Public regulatory relief and the adoption of environmental management systems: A European survey. Journal of Environmental Planning and Management, 59(12), 2231-2250.

16. Testa, F., Boiral, O., Iraldo, F. (2018). Internalization of environmental practices and institutional complexity: Can stakeholders pressures encourage greenwashing? Journal of Business Ethics, 147(2), 287-307.

17. Yang, F., Zhang, X. (2017). Analysis of the barriers in implementing environmental management system by interpretive structural modeling approach. Management Research Review, 40(12), 1316.

18. Zhu, Q., Cordeiro, J., Sarkis, J. (2013). Institutional pressures, dynamic capabilities and environmental management systems: Investigating the ISO 9000-Environmental management system implementation linkage. Journal of Environmental Management, 114, 232-242. 